\title{
EFFECT OF DIFFERENT LEVELS OF SALINITY ON SEED GERMINATION OF FOUR SELECTED TREE SPECIES
}

\author{
S Subasinghe and WGD Lakmini \\ Department of Crop Science, Faculty of Agriculure, University of Ruhuna, Mapalana
}

Salinity is one of the most adverse factors, which restrict the economic utilization of available land resources in the dry zone of Sri Lanka. The salt affected area in Sri Lanka is estimated about 223,000 ha, which comprises $3 \%$ of the land area of the Island, found mainly in the dry zone (Vivekanandan, 1989). The most of the salt affected lands are generally barren, with little woody vegetation of salt tolerant bushes and herbaceous flora. This resulted in serious soil erosion and land degradation problems, which spreids into adjoining productive agricultural lands too. Therefore it is very important to restore these lands for useful agricultural purposes. In this context, the present study was mainly focused to determine the effect of salinity on seed germination of four selected tree species, namely Castor (Ricinus communis), Ipil-ipil (Leucenea leucocephala), Wood apple (Feronia limonia) and Kottamba (Terminalia catappa) in order to study the possibility to regenerate these tree species by direct seeding in salt affected lands.

Four separate pot experiments were conducted by using above four tree species in sand trays. All experiments were arranged in a Complete Randomized Design with 5 replicates. 100 seeds were planted in each tray for germination. Trays were kep moist with different levels of saline water (i.e. 0.13 (normal water) $4,8,12,16,24,32$, and 40 (Seawater) $\mathrm{mmhos} / \mathrm{cm}$ ) by diluting seawater as assigned in different treatments throughout the experimental period.

Result revealed that seed germination in control treatments was higher in Wood apple $(100 \%)$ and Castor (72\%) than Kottamba (31\%) and Ipil-ipil (13\%). Seed germination was decreased with increasing level of saline level in Kottamba and Castor. In Kottamba, no germination was observed at all when at salinity level increased up tc $26 \mathrm{mmhos} / \mathrm{cm}$ while in Castor germination was nil when salinity level increased up to $40 \mathrm{mmhos} / \mathrm{cm}$. In Wood apple, more than $80 \%$ of germination was recorded even up to the salinity level of $24 \mathrm{mmhos} / \mathrm{cm}$. Germination was poor in Ipil-ipil even in control treatment and not significantly decreased up to the salinity level of 40 $\mathrm{mmhos} / \mathrm{cm}$.

Therefore, the species can be ranked in order to tolerance to salinity in terms of germination as follows: Ipil-ipil $>$ Wood apple $>$ Castor $>$ Kottamba. 